\title{
Identification of Malaysia's Edible Bird's Nest Geographical Origin Using Gel Electrophoresis Analysis
}

\author{
Ting Hun Lee ${ }^{1, *}$, Syieluing Wong ${ }^{1}$, Chia Hau Lee ${ }^{1}$, Nurul Alia Azmi', \\ Murugiah Darshini $^{1}$, Supparmaniam Kavita ${ }^{1}$, and Kian Kai Cheng ${ }^{1}$ \\ ${ }^{1}$ School of Chemical and Energy Engineering, Faculty of Engineering, Universiti \\ Teknologi Malaysia, 81310 Skudai, Johor, Malaysia \\ *Corresponding author. E-mail: leetinghun@utm.my \\ https://doi.org/10.12982/CMUJNS.2020.0025 \\ Received: June 27, 2019 \\ Revised: August 12, 2019 \\ Accepted: August 19, 2019
}

\begin{abstract}
There is an urgent need to develop a rapid and robust approach to ensure traceability of the Edible Bird's Nest (EBN) products. The main composition of $E B N$ is protein and it plays an important role in EBN. This study shows that there are significant differences in the protein profile of $E B N$ collected from different states in Malaysia. The SDS-PAGE method is used to analyse the protein profile for 65 samples collected from 13 different states of Malaysia. SDS-PAGE gel image showed that all EBN samples analyzed have been well separated between protein bands. Data shows that protein band at $212 \mathrm{kD}$ can only be detected in state $P$, while $135 \mathrm{kD}$ can only be found in state $\mathrm{M} . \mathrm{EBN}$ from other states have their unique combination of fingerprints that made them different from one to another. This research demonstrated the possibility of using SDS-PAGE pattern for identification and differentiation of the geographical origins of EBN produced in Malaysia. These findings are the first of its kind in EBN analysis.
\end{abstract}

Keywords: Edible bird's nest, Identification, Geographical origin, Sodium Dodecyl Sulfate Polyacrylamide Gel electrophoresis (SDS-PAGE), Protein profiling

\section{INTRODUCTION}

Edible bird's nest (EBN) is produced by the secretion of swiftlets Aerodramus fuciphagus (white-nest swiftlets) and Aerodramus maximus (blacknest swiftlets) during breeding season. EBN or 'Yan Wo' in Chinese is a 
traditional cuisine and delicacy among the Chinese society, mainly due to its rich nutrient content such as sialic acid, carbohydrate, amino acid and epidermal growth factor-like protein (Chan et al., 2013; Chua et al., 2013; Lee et al., 2015). Traditionally, EBN is harvested in caves, a natural habitat of the swiftlets. However, the development of swiftlets ranching technique (Chua and Zukefli, 2016), which began in the 70s, has successfully lured the swiftlets into the manmade buildings. These are artificial habitats for the swiftlets which are termed as "swiftlet premises". This has greatly enhanced the EBN yield in Malaysia. Initiatives by the Malaysian government in the form of policy development and a subsidiary of technology advancement contribute further to the tremendous success of the EBN industry in Malaysia. Currently, Malaysia is the second largest EBN exporter in the world after Indonesia. Out of the annual production of 350 metric tonnes of EBN by Malaysia reported in 2016, 130 tonnes were exported to other countries, with China as the main one (The Star, 2016).

One of the efforts promoted by this paper is to protect the EBN consumers from choosing the wrong EBN. The enterprises that export their products to China are required to register under Certification and Accreditation Administration of the People Republic of China (CNCA). The Chinese Academy of Inspection and Quarantine (CAIQ) also designed the EBN traceability and management service platform, which enables the consumers to obtain the necessary information on every single EBN product from production to product delivery through a unique barcode and serial number attached to each product. Nevertheless, the validity of such system depends solely on the reputation and honesty of the producers and distributors. However, it is necessary to develop an analysis method to verify the geographical origins of the EBN by the governing bodies. A study by Quek et al. (2018b) involved the characterization of EBN from different origins based on their nutritional, physicochemical and antioxidant characteristics. The team also found higher mercury and arsenic levels in EBN from the house nests. This phenomenon is likely to have arisen due to the rapid development in urban areas which leads to higher contamination to the environment and swiftlets' diet. The same research team also developed SINS- and SYBR-based real-time PCR methodologies that are able to identify the swiftlet species and production origins, based on four genes (Cyt b, ND2, 12S and Fib7) and two phylogenetic tree methods (Quek et al., 2018a). Such methods are possible due to the more rapid mutation and evolutional rates in the protein coding genes of the swiftlets, which lead to more variable nucleotide sites. Nevertheless, all these methods could not differentiate the geographical origins of the EBN with high accuracy. Hence, it is necessary to search for an analytical method that could accomplish such objective.

Traceability is an important element in businesses related to fresh produce and animal food around the globe. This includes and is not limited to seafood, olive oil, potatoes, mushrooms, meats etc. It provides a protection against food 
adulteration, counterfeiting and over-claiming to the other more reputable sources. Following the rise of consumer awareness on food quality and safety, various analysis methods have been developed to ensure the traceability of food. Among the analytical approaches studied, gel electrophoresis remains to be a popular option, as such method is simple in operation, consumes less cost and offers high sensitivity to the sample compared to other electrophoresis methods. This method involves the separation and subsequent identification of DNA/RNA/proteins that are specific to the geographical origins of the food. Andrade et al. (1997) are among the early research teams that demonstrated the potential of gel electrophoresis in identifying the food origins. Their work involved the separation of phenolic compounds contained in 26 honey samples from different floral origins. The phenolic compounds profiles were compared and they were able to reveal several unique compounds that could be used as markers for floral origin identification. Le Nguyen et al. (2008) showed geographical origins of the fishes (Pangasius hypophthalmus) could be detected by identifying the bacteria accumulated on the fish skins, gills and intestines using Polymerase Chain Reaction Denaturing Gadient Gel Electrophoresis (PCRDGGE). The differences observed in the 16S rDNA banding profile of the fish's bacteria could be attributed to the unique combinations of the following characteristics of the fish habitat: feeding method, type of aquaculture, possible contaminants in the water, the use of antibiotics and the stress factor. Sodium Dodecyl Sulfate Polyacrylamide Gel Electrophoresis (SDS-PAGE) was employed to distinguish the different species of puffer fishes based on the various species-specific at lower molecular weight protein bands (Chen and Hwang, 2002). Li et al., 2018, used SDS-PAGE to identify the geographical origins for Ganoderma lucidum. Their findings revealed that there were significant differences in the protein profile of Ganoderma lucidum from different origins.

In view of the successful application of SDS-PAGE for geographical identification as mentioned above, it is worthy to study the potential of such method on EBN in Malaysia. This study aims to identify the unique marker of EBN from each and every State in Malaysia.

\section{MATERIALS AND METHODS}

\section{Chemical reagents and apparatus}

The chemicals and reagents used in this study were of analytical grade such as 10X Tris/Glycine/SDS Buffer (Bio-Rad), 2-mercaptoethanol (Sigma), Acrylamide (R\&M Chemical), Ammonium Persulfate (APS) (Sigma), Bromophenol Blue Sodium salt (Sigma), Coomassie Brilliant Blue R-250 (Sigma), Glacial Acetic Acid (Merck), Glycerol (Sigma), N,N,N',N'Tetramethylethane-1,2-ethylenediamine (TEMED) (GE Healthcare Biosciences), Protein molecular weight marker (Promega Corporation), Sodium 
Dodecyl Sulphate or Lauryl Sulphate (SDS) (Bio-Rad), 0.5 M Tris-HCL Buffer (Bio-Rad), 1.5 M Tris-HCL Buffer (Bio-Rad), Methanol (QReC). The apparatus and equipment used in this study were Bio-Rad Mini-Protean III apparatus, Power supply (capacity $200 \mathrm{~V}, 500 \mathrm{~mA}$ ), Oven (Memmert, USA), Grinder (Da Xiang, 1,000 g), Steel filter $(1 \mathrm{~mm})$, Sterile Bottles, Water Bath (Memmert, USA), Scanner (Canon Pixma G2000), Rotary shaker (Innovo 4080), $15 \mathrm{~mL}$ Falcon tubes.

\section{Edible Bird's Nest sample}

Raw unclean EBN samples (house nests) were collected from a total of thirteen states in Malaysia from 2014 to 2017. These samples were collected directly from the swiftlet premises by experienced farmers or harvesters and labeled with their places of origin to avoid any mishandling and unvalidated place of origin. A total of 5 samples were collected from every state. An industrial cleaning method was adapted and standardised to clean the collected EBN samples in the laboratory in order to prevent the contamination of protein sources from the environment according to Good Manufacturing Practice (GMP) For Processing Raw-Unclean and Raw-Clean Edible Bird's Nest (MS 2333:2010). In brief, the unclean EBN (coded UC) were sprayed with distilled water on the surface individually and left for 2 hours to allow swelling of its strains. The impurities and feathers in the UC were picked and cleaned, and the cleaned EBN were coded ' $\mathrm{C}$ '. These cleaned samples were then dried in an oven at $40{ }^{\circ} \mathrm{C}$ for 5 hours or until constant weight was achieved, whichever was earlier.

\section{EBN sample preparation for analysis}

Cleaned (C) and unclean (UC) samples of EBN were separately ground into powder using a grinder (Da Xiang, 1,000g), and sieved through a $1 \mathrm{~mm}$ steel filter to ensure an even size. The powdered EBN samples, clean and unclean, were then kept in separate sterile bottles and labeled according to their location collected and types. All samples were then stored at room temperature until further use.

\section{Protein extraction}

This extraction method was adapted from several reports (Kong et al., 1987; Oda et al., 1998; Goh et al., 2001; Chan et al., 2015; Hun et al., 2016) with slight modifications. Each EBN sample $(0.5 \mathrm{~g})$ was immersed in $50 \mathrm{~mL}$ distilled water and allowed to stand overnight (more than 15 hours) at $5{ }^{\circ} \mathrm{C}$. This step ensured the content of sialic acid in the EBN can be removed by soaking in coldwater which may affect the performance of electrophoresis (Ma and Liu, 2012). Then, the extract was incubated at $80{ }^{\circ} \mathrm{C}$ in a shaker (Innovo 4080) for 5 hours. The extracted solution was centrifuged at 4,000 rpm for 15 minutes (Kubota 2010). The supernatant was transferred into a fresh sample tube and stored at 4 ${ }^{\circ} \mathrm{C}$. 


\section{SDS gel preparation}

The $12.5 \%$ separating gel and $4 \%$ stacking gel were prepared according to Bio-Rad Mini-Gel manufacturer's instruction. The preparation of $12.5 \%$ separating gel included the complete mixing of 1.5 M Tris-HCL buffers ( $\mathrm{pH} 8.8$ ), $10 \%$ of SDS, $30 \%$ acrylamide solution and deionized water in a $15 \mathrm{~mL}$ Falcon tube. Then, TEMED and $10 \%$ APS were added into the mixtures. After that, the separating gel solution was transferred into a gel sandwich at $1 \mathrm{~cm}$ height, and then polymerized for 45 mins. This was followed by the removal of the water layer using filter paper.

The $4 \%$ stacking gel was prepared by complete mixing of $0.5 \mathrm{M}$ Tris-HCL buffer ( $\mathrm{pH}$ 6.8), $10 \%$ of SDS, $30 \%$ acrylamide solution, deionized water, TEMED and $10 \%$ APS. The mixture was then poured onto the separating gel and the gel comb was inserted carefully into the stacking gel to prevent bubble formation during the process. The mixture was polymerized for one hour. The gel comb was removed after the stacking gel polymerization, then the sample hole was formed, and the gel was ready to use.

\section{SDS-PAGE analysis}

The protein profiles of the samples were analysed by SDS-PAGE as demonstrated in a previous study (Hun et al., 2016). The supernatant from each sample was diluted with deionized water (ratio of 1:3). Then, the protein sample was directly treated with $5 \mathrm{X}$ loading buffer $(0.5 \mathrm{M}$ Tris-HCL buffer, $\mathrm{pH} 6.8,50$ $\%$ Glycerol, $10 \%$ SDS, 2-mercaptoethanol, $1 \%$ bromophenol blue and deionized water) (ratio of 4:1). After that, the reaction mixture was centrifuged (Kubota 2010) for 30 seconds, followed by heating at $95{ }^{\circ} \mathrm{C}$ for 5 minutes in a water bath, and subsequently centrifuged again at 2,000 rpm for 5 minutes. The profile of the extracted protein was analyzed using SDS-PAGE (Bio-Rad Mini-Protean III). The analysis consists of loading of $5 \mathrm{uL}$ protein, as well as standard protein marker (Promega Corporation) onto $4 \%$ stacking gel and $12.5 \%$ separating gel. The gel electrophoresis was conducted at $100 \mathrm{~V}(15 \mathrm{~A})$ for 95 minutes, then the gel was stained (1 \% Coomassie Brilliant Blue R-250, $50 \%$ methanol, $10 \%$ glacial acetic acid) for 20 minutes. After that, the staining solution was discarded by solution consisting $40 \%$ methanol, $10 \%$ glacial acetic acid. Then, the protein profiles of all samples were visualized by a scanner (Canon Pixma G2000).

\section{Detection of protein marker}

\section{RESULTS}

Prior to the determination of the protein profiles in the EBN samples, the standard protein markers were used to detect the protein bands in EBN samples. As shown in Figure 1, the correct molecular weight $(\mathrm{kD})$ of standard proteins were obtained at $14.4 \mathrm{kD}, 21.5 \mathrm{kD}, 31 \mathrm{kD}, 45 \mathrm{kD}, 66.2 \mathrm{kD}, 97.4 \mathrm{kD}, 116 \mathrm{kD}$ and $212 \mathrm{kD}$ in SDS-PAGE gel electrophoresis. 


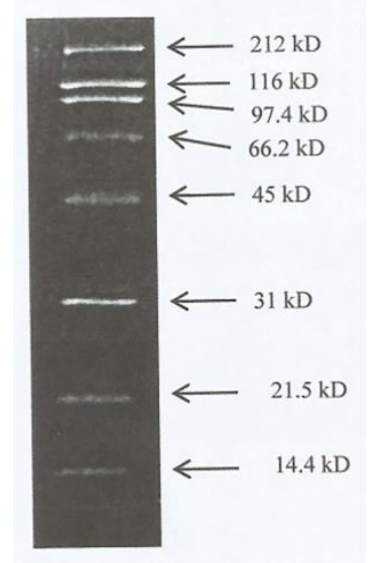

Figure 1. Molecular weight of standard protein markers.

\section{Detection of protein profile from EBN}

The protein profiles of the EBN from different states in Malaysia are depicted in Figures 1. All the five replicates for EBN samples collected from each state produced similar protein profiles, and there was no appreciable difference between clean and unclean EBN from the same state. Such observation indicates that industrial cleaning method does not alter its protein content significantly. Nevertheless, distinctive protein band patterns can be observed for EBN from different states. The EBN obtained from location $\mathrm{P}$ showed the highest number of protein band, 18. This was followed by those collected from locations $\mathrm{K}$ and $\mathrm{M}, 17$ bands. The EBN collected from locations $\mathrm{A}, \mathrm{C}$ and $\mathrm{D}$ displayed 16 protein bands, while 15 bands were observed for EBN samples from B, J, N, Q and T, and 14 bands for EBN from R. Samples from location $S$ exhibited the lowest number of protein bands with 11 protein brands. These findings clearly showed that EBN from different states in Malaysia contain their own unique protein profile patterns which could serve as fingerprint. For the readers' convenience, the bands detected from all EBN samples were summarized in Table 1.

It is also found that protein bands identified in all EBN samples lie in the range of $16-212 \mathrm{kD}$. Five common bands $(16 \mathrm{kD}, 19 \mathrm{kD}, 21 \mathrm{kD}, 66 \mathrm{kD}$ and 116 $\mathrm{kD})$ were detected in all the thirteen states whereas two specific bands $(20 \mathrm{kD}$ and $212 \mathrm{kD})$ were found in location P samples and one band $(135 \mathrm{kD})$ was found in location M samples. On the other hand, ten bands $(23 \mathrm{kD}, 25 \mathrm{kD}, 27 \mathrm{kD}, 30 \mathrm{kD}$, $33 \mathrm{kD}, 37 \mathrm{kD}, 42 \mathrm{kD}, 49 \mathrm{kD}, 56 \mathrm{kD}$ and $97.4 \mathrm{kD}$ ) were detected in EBN samples from eight different places of origins while nine bands $(31 \mathrm{kD}, 35 \mathrm{kD}, 47 \mathrm{kD}, 58$ $\mathrm{kD}, 80 \mathrm{kD}, 85 \mathrm{kD}, 154 \mathrm{kD}$, and $173 \mathrm{kD}$ ) were detected in five places of origins. The bands with molecular weights of $41 \mathrm{kD}, 82 \mathrm{kD}$ and $148 \mathrm{kD}$ were detected in six, seven and five states respectively. 
a
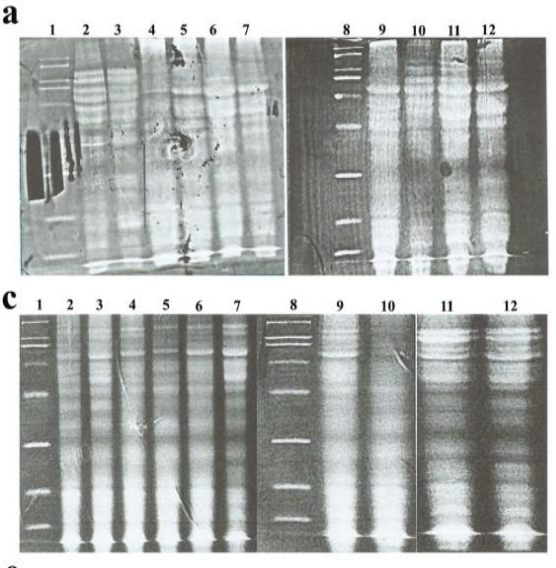

e
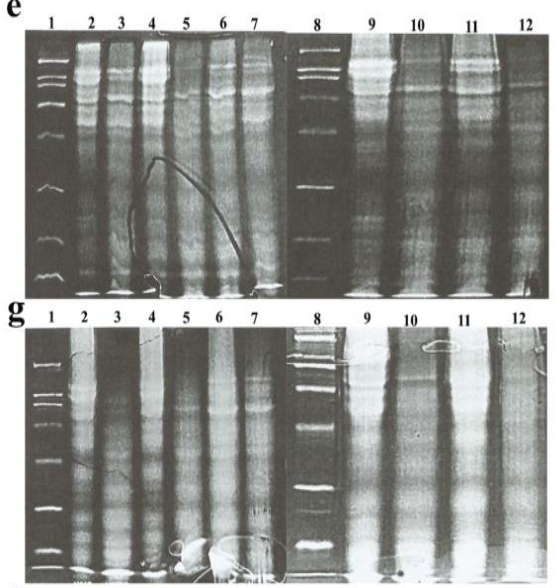

i
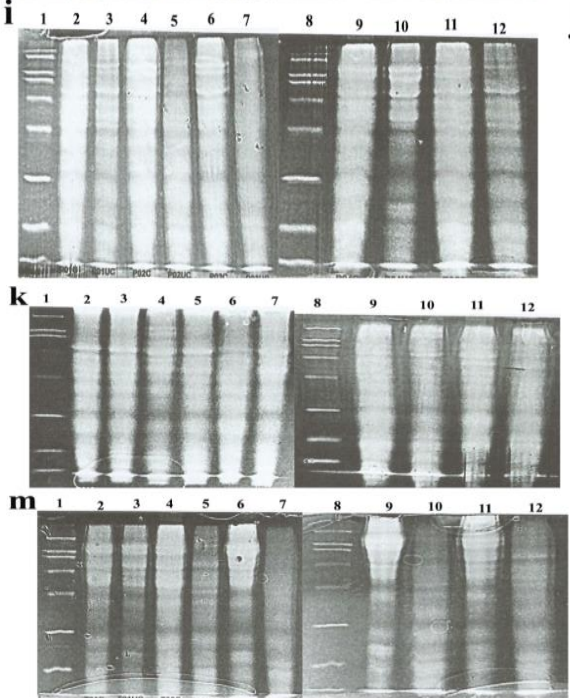
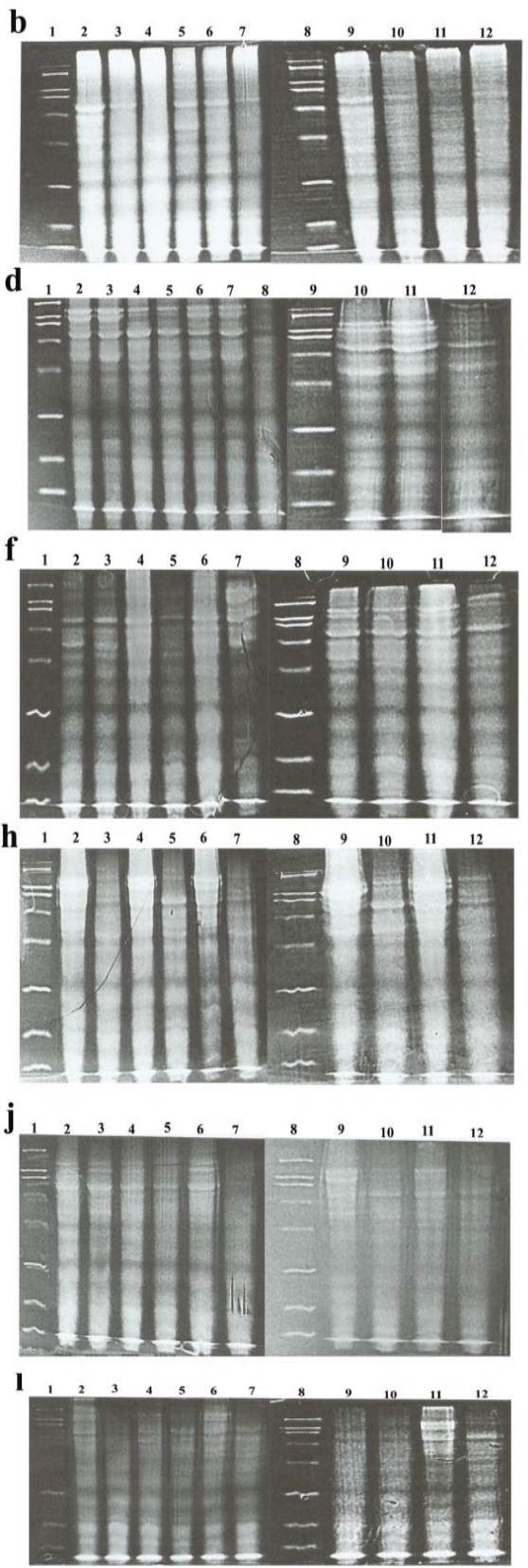

Figure 2. SDS-PAGE result for five clean and five unclean EBN samples. Lane 1 and 8 are standard protein markers; Lane 2, 4, 6, 9, 11 are clean EBN; Lane 3, 5, 7, 10, 12 are unclean EBN for (a) Location A; (b) Location B; (c) Location C; (e) Location J; (f) Location K; (g) Location M; (h) Location N; (i) Location P; (j) Location Q; (k) Location R; (1) Location S; (m) Location T. For, (d) Location D; Lane 1 and 9 are standard protein markers; Lane 2, 4, 6, 8, 11 are clean EBN; Lane 3, 5, 7, 10, 12 are unclean EBN. 
Table 1. Protein band detected from thirteen states with $(n=5)$ of EBN samples.

\begin{tabular}{|c|c|c|c|c|c|c|c|c|c|c|c|c|c|c|}
\hline MW & $\overline{\mathbf{A}}$ & B & $\bar{C}$ & D & $\overline{\mathbf{J}}$ & $\mathbf{K}$ & $\mathbf{M}$ & $\mathbf{N}$ & $\overline{\mathbf{P}}$ & $\mathbf{Q}$ & $\overline{\mathbf{R}}$ & $\bar{S}$ & $\mathbf{T}$ & $\begin{array}{c}\text { Total } \\
\text { Protein }\end{array}$ \\
\hline 212 & - & - & - & - & - & - & - & - & Yes & - & - & - & - & 1 \\
\hline 173 & - & - & - & - & Yes & - & - & - & Yes & - & - & - & - & 2 \\
\hline 154 & Yes & - & - & Yes & - & Yes & - & - & - & - & - & - & - & 3 \\
\hline 148 & - & Yes & - & - & - & - & - & Yes & - & Yes & $\begin{array}{l}\text { Yes } \\
(144)\end{array}$ & - & Yes & 5 \\
\hline 135 & - & - & - & - & - & - & Yes & - & - & - & - & - & - & 1 \\
\hline 116 & Yes & Yes & Yes & Yes & Yes & Yes & Yes & Yes & Yes & Yes & Yes & Yes & Yes & 13 \\
\hline 97.4 & Yes & Yes & Yes & Yes & Yes & Yes & Yes & Yes & - & - & Yes & - & - & 9 \\
\hline 85 & - & - & - & - & - & $\begin{array}{l}\text { Yes } \\
(84)\end{array}$ & - & - & - & $\begin{array}{l}\text { Yes } \\
(87)\end{array}$ & - & - & - & 2 \\
\hline 82 & Yes & - & - & Yes & Yes & - & - & Yes & Yes & Yes & Yes & - & - & 7 \\
\hline 80 & - & Yes & Yes & - & - & - & Yes & - & - & - & - & - & Yes & 4 \\
\hline 66 & Yes & Yes & Yes & Yes & Yes & Yes & Yes & Yes & Yes & Yes & Yes & Yes & Yes & 13 \\
\hline 58 & - & - & Yes & - & Yes & Yes & - & - & - & - & - & Yes & - & 4 \\
\hline 56 & Yes & Yes & $\begin{array}{l}\text { Yes } \\
(54)\end{array}$ & Yes & - & - & Yes & Yes & Yes & Yes & $\begin{array}{l}\text { Yes } \\
(54)\end{array}$ & - & Yes & 10 \\
\hline 49 & Yes & - & Yes & Yes & $\begin{array}{l}\text { Yes } \\
(51)\end{array}$ & Yes & Yes & Yes & Yes & - & Yes & - & - & 9 \\
\hline 47 & - & Yes & - & - & - & - & - & - & - & Yes & - & Yes & Yes & 4 \\
\hline 42 & $\begin{array}{l}\text { Yes } \\
(43)\end{array}$ & Yes & - & - & $\begin{array}{l}\text { Yes } \\
(43)\end{array}$ & Yes & $\begin{array}{l}\text { Yes } \\
(43)\end{array}$ & - & Yes & Yes & - & Yes & Yes & 9 \\
\hline 41 & $\begin{array}{l}\text { Yes } \\
(40)\end{array}$ & - & Yes & Yes & - & - & Yes & Yes & - & - & Yes & - & - & 6 \\
\hline 37 & Yes & Yes & - & Yes & Yes & Yes & Yes & - & Yes & - & Yes & - & $\begin{array}{l}\text { Yes } \\
\text { (39) }\end{array}$ & 9 \\
\hline 35 & - & - & Yes & - & - & Yes & - & - & - & Yes & - & Yes & - & 4 \\
\hline 33 & - & Yes & Yes & Yes & - & - & Yes & Yes & Yes & - & Yes & - & Yes & 8 \\
\hline 31 & - & - & - & - & - & - & Yes & Yes & Yes & - & - & - & - & 3 \\
\hline 30 & Yes & Yes & Yes & Yes & Yes & Yes & - & $\begin{array}{l}\text { Yes } \\
(29)\end{array}$ & - & - & - & - & Yes & 8 \\
\hline 27 & Yes & Yes & - & - & Yes & Yes & Yes & - & Yes & Yes & - & Yes & - & 8 \\
\hline 25 & - & - & Yes & Yes & Yes & Yes & - & Yes & Yes & Yes & - & - & Yes & 8 \\
\hline 23 & Yes & - & Yes & Yes & - & Yes & Yes & - & Yes & Yes & Yes & Yes & Yes & 10 \\
\hline 21 & Yes & Yes & Yes & Yes & Yes & Yes & Yes & Yes & Yes & Yes & Yes & Yes & Yes & 13 \\
\hline 20 & - & - & - & - & - & - & - & - & Yes & - & - & - & - & 1 \\
\hline 19 & Yes & Yes & Yes & Yes & Yes & Yes & Yes & Yes & Yes & Yes & Yes & Yes & Yes & 13 \\
\hline 16 & Yes & $\begin{array}{l}\text { Yes } \\
(17)\end{array}$ & Yes & Yes & $\begin{array}{l}\text { Yes } \\
(15)\end{array}$ & Yes & Yes & Yes & Yes & Yes & Yes & Yes & Yes & 13 \\
\hline $\begin{array}{l}\text { Total } \\
\text { Protein }\end{array}$ & 16 & 15 & 16 & 16 & 15 & 17 & 17 & 15 & 18 & 15 & 14 & 11 & 15 & \\
\hline
\end{tabular}


Based on the electrophoretograms of the EBN collected from 13 states (Figure 2), several bioactive proteins were identified and reported by other researchers. In this study, the five common bands such as $16 \mathrm{kD}, 19 \mathrm{kD}, 21 \mathrm{kD}$, $66 \mathrm{kD}$ and $116 \mathrm{kD}$ were detected in all samples. Among these, $66 \mathrm{kD}$ protein was reported as an allergen protein in EBN as mentioned by Goh et al. (2001). $\mathrm{Ou}$ et al. (2001) also reported that the major allergens in EBN were detected in $66 \mathrm{kD}$ protein band, which were found to be homologous to ovoinhibitor. As EBN are consumed by people of different age groups, it is important to highlight the possibility of EBN in causing anaphylaxis and hypersensitivity (Goh et al., 2001). Moreover, the protein band at $49 \mathrm{kD}$ in location A, C, D, J, K, M, N, P and S is suspected to be an Acidic mammalian chitinase-like (AMCase-like) protein, based on studies by several researchers that attributed the protein band at $50 \mathrm{kD}$ to AMCase-like protein (Liu et al., 2012; Wong et al., 2017). From their reports, AMCase-like protein originates from Meleagris gallopavo (wild turkey). Such ambiguity arose due to the lack of complete genome sequence of Aerodramus, which presented a challenge for protein identification in EBN and thus to the partial sequence homology of M. gallopavo protein (Liu et al., 2012; Wong et al., 2017). The remaining protein bands composition detected are still unknown and further work is required to identify these compositions in EBN.

\section{DISCUSSION}

Consumers are becoming increasingly careful and demanding about the food they eat and where they come from. This could easily relate to the products with the producing environment trace elements, pollutants and even culture behind it. Therefore, the capability to certify the origin of the food produced is becoming important in the market. A very good example is found in Europe, which uses geographical indications and traditional specialties known as Protected Designation of Origin (PDO), Protected Geographical Indication (PGI) and Traditional Specialties Guaranteed (TSG) to promote and protect the names of products. The purpose of enforcing these schemes is to protect the reputation of the regional foods, help manufacturers or producers obtain a premium price for their unique origin of products and eliminate unfair competition and misleading of consumers by non-genuine products (Gonzalvez et al., 2009; Salim et al., 2018).

EBN is one of the National Key Economic Areas (NKEA) for the agricultural sector under the Economic Transformation Programme (ETP) in Malaysia. It is also well-known that EBN is one of the most valuable and widely used Traditional Chinese Medicine (TCM) (Lee et al., 2015). The origin of EBN comprises different protein profile (Figure 2 and Table 1 ), it could lead to quality grading. With this identification method, it could recognize the geographical origin of EBN and it is possible to detect any illegal and false claims on EBN origin and hence, it can protect the consumer's right. It is also a good way to 
countercheck or can be used as an enforcement analysis method to detect false claims.

Protein is the major component in EBN. Our previous study (Hun et al., 2015), has successfully characterized protein content, $35.80 \%$ (w/w). This result falls between the range $42 \%-63 \%$ (w/w) reported by Ma and Liu (2012). It is possible to use protein as the biomarkers for EBN (Chua et al., 2014). Protein extraction could be challenging and results in inconsistency which becomes a difficult task for researchers (Mehmeti et al., 2011). Finding the appropriate technique for protein extraction was the preliminary step in the detection and identification of protein which had been done from our previous worked (Hun et al., 2016). With the optimized SDS-PAGE method used based on the previous study is a vital step in a gel-based proteomics approach and is absolutely essential for reproducible results. With the result, the SDS-PAGE detection technique allowed rapid and cost-effective analysis to be undertaken by researchers and other interested parties. This common method for separation and visualization of proteins from crude extracts of samples is still commonly being used until today due to its simplicity, availability and cost-effective. Consequently, SDS-PAGE reveals the characteristic of protein band patterns. This includes and is not limited to protein sources from insects, mushrooms, seafood, plants, bacteria, etc (Chart, 2018; Li et al., 2018; O'Neill et al., 2018; Sahin et al., 2018; Popoola et al., 2019). With the advantages described above, the EBN protein has been profiled and lead to the identification of the geographical origin of Malaysia EBN.

It is worth mentioning that this study was carried out together with the effort of the relevant local authorities in Malaysia to ensure the reliability of the geographical origins of the EBN samples. Many researchers are not familiar with the whole eco-business system of EBN and rely heavily on the processors, ranchers or even retailers on the geographical origins of EBN samples used in their studies. Such practice could lead to erroneous results and the subsequent analysis. In addition, the different EBN cleaning and processing methods could affect the EBN quality in different ways. To avoid inaccurate results which arise from human factor, the EBN should be collected by the researchers and the cleaning method must be standardized in order to produce accurate and reliable results.

Nevertheless, this work demonstrated that EBN from different geographical origins in Malaysia possesses different protein bands with varying intensity. This may be attributed to the different conditions of the swiftlets habitats, localization, and diets. The findings of this study indicate the suitability of the SDS-PAGE method in complementing the present EBN traceability system. Other possible methods has used for authentication and identification of EBN were Genetics-based techniques (Guo et al., 2014), Enzyme-linked immunosorbent assays (ELISAs) (Tukiran et al., 2016), Spectroscopic (Shim et al., 2016) and Chromatographic (Tung et al., 2008). However, these methods 
were not cost-effective and also the needs of setting up sophisticated instruments (Lee et al., 2017). Compared to the other methods, the overarching advantage of SDS-PAGE method is that the sample processing protocol is simple and easy to implement. Li et al. (2018) used SDS-PAGE and two-dimensional electrophoresis (2-DE) protein profile and found significant differences in the protein profile of Ganoderma lucidum from different origins. They also concluded that it is able to use SDS-PAGE and 2-DE for the identification of different samples. Another work is done by O'Neill et al. (2018) to identify soft-bodied wood boring insect larvae with SDS-PAGE. The technique was feasible for identifying soft-bodied insect larvae. Furthermore, another paper had done by Chen and Hwang (2002) by using SDS-PAGE to the identification of puffer fish species. It showed that SDS-PAGE has been used to carry out similar identification work on other subjects matter.

\section{CONCLUSION}

This study demonstrates the high potential of SDS-PAGE as a fast, accurately, reliable and relatively economical analysis method in identifying the geographical origins of the EBN. This method used SDS-PAGE gel electrophoresis to analyse the EBN based on the protein molecular weight. This research also successfully presents a unique fingerprinting of protein profile from every state in Malaysia. Therefore, this fingerprint can be used as a standard for identification and differentiation of the geographical origins of EBN in Malaysia.

\section{ACKNOWLEDGMENTS}

This study was supported by the Research University grant (GUP, grant number 10J74).

\section{REFERENCES}

Andrade, P., Ferreres, F., Gil, M.I., and TomasBarberan, F.A. 1997. Determination of phenolic compounds in honeys with different floral origin by capillary zone electrophoresis. Food Chemistry. 60(1): 79-84. https://doi.org/10.1016/S0308-8146(96)00313-5

Chan, G.K., Zheng, K.Y., Zhu, K.Y., Dong, T.T., and Tsim, K.W. 2013. Determination of free $\mathrm{N}$-acetylneuraminic acid in edible bird nest: $\mathrm{A}$ development of chemical marker for quality control. Journal of Ethnobiology and Traditional Medicine. 120: 620-628.

Chan, G.K., Wong, Z.C., Lam, K.Y., Cheng, L.K., Zhang, L.M., Lin, H., Dong, T.T., and Tsim, K.W. 2015. Edible bird's nest, an Asian health food supplement, possesses skin lightening activities: identification of $\mathrm{N}$-acetylneuraminic acid as active ingredient. Journal of Cosmetics, Dermatological Sciences and Applications. 5(4): 262-274.https://doi.org/ $10.4236 /$ jcdsa.2015.54032 
Chart, H. 2018. Bacterial fractionation and membrane protein characterization. Methods in practical laboratory bacteriology. CRC Press. p. 1-10.

Chen, T.Y., and Hwang, D.F. 2002. Electrophoretic identification of muscle proteins in 7 puffer species. Journal of Food Science. 67: 936-942. https://doi.org/10.1111/j.1365-2621.2002.tb09431.x

Chua, K.H., Lee, T.H., Nagandran, K., Md Yahaya, N.H., Lee, C.T., Tjih, E.T., and Abdul Aziz, R. 2013. Edible bird's nest extract as a chondro-protective agent for human chondrocytes isolated from osteoarthritic knee: in vitro study. BMC Complementary and Alternative Medicine. 13: 19. https://doi. org/10.1186/1472-6882-13-19

Chua, Y.G., Bloodworth, B.C., Leong, L.P., and Li, S.F.Y. 2014. Metabolite profiling of edible bird's nest using gas chromatography/mass spectrometry and liquid chromatography/mass spectrometry. Rapid Communications in Mass Spectrometry. 28(12): 1387-1400. https://doi.org/10.1002/rcm.6914

Chua, L.S., and Zukefli, S.N. 2016. A comprehensive review on edible bird nests and swiftlet farming. Journal of Integrative Medicine. 14(6): 415-428. https://doi.org/10.1016/S2095-4964(16)60282-0

Goh, D.L.M., Chua, K.Y., Chew, F.T., Liang, R.C.M.Y., Seow, T.K., Ou, K.L., Yi, F.C., and Lee, B.W. 2001. Immunochemical characterization of edible bird's nest allergens. Journal of Allergy and Clinical Immunology. 107: 1082-1088. https://doi.org/10.1067/mai.2001.114342

Gonzalvez, A., Armenta, S., and de la Guardia, M. 2009. Trace-element composition and stable-isotope ratio for discrimination of foods with protected designation of origin. Trac-Trends in Analytical Chemistry. 28: 1295-1311. https://doi.org/10.1016/j.trac.2009.08.001

Guo, L., Wu, Y., Liu, M., Wang, B., Ge, Y., and Chen, Y. 2014. Authentication of edible bird's nests by TaqMan-based real-time PCR. Food Control. 44: 220-226. https://doi.org/10.1016/j.foodcont.2014.04.006

Hun, L.T., Wani, W.A., Tjih, E.T.T., Adnan, N.A., Ling, L., and Aziz, R.A. 2015. Investigations into the physicochemical, biochemical and antibacterial properties of edible bird's nest. Journal of Chemical and Pharmaceutical Research. 7: 228-247.

Hun, L.T., Wani, W.A., Poh, H.Y., Baig, U., Tjih, E.T.T., Nashiruddin, N.I., Ling, Y.E., and Aziz, R.A. 2016. Gel electrophoretic and liquid chromatographic methods for the identification and authentication of cave and house edible bird's nests from common adulterants. Analytical Methods. 8: 526-536. https://doi.org/10.1039/C5AY02170G

Kong, Y., Keung, W., Yip, T., Ko, K., Tsao, S., and Ng, M. 1987. Evidence that epidermal growth factor is present in swiftlet's (Collocalia) nest. Comparative Biochemistry and Physiology B, Comparative Biochemistry. 87: 221-226. https://doi.org/10.1016/0305-0419(87)90133-7 
Lee, T.H., Wani, W.A., and Eddie, T.T.T. 2015. Edible bird's nest: An incredible salivary bioproduct from swiftlets. Germany: LAP LAMBERT Academic Publishing.

Lee, T.H., Wani, W.A., Koay, Y.S., Kavita, S., Tan, E.T.T., and Shreaz, S. 2017. Recent advances in the identification and authentication methods of edible bird's nest. Food Research International. 100: 14-27. https://doi.org/10.10 16/j.foodres.2017.07.036

Le Nguyen, D.D., Ngoc, H.H., Dijoux, D., Loiseau, G., and Montet, D. 2008. Determination of fish origin by using $16 \mathrm{~S}$ rDNA fingerprinting of bacterial communities by PCR-DGGE: an application on Pangasius fish from Vietnam. Food Control. 19: 454-460. https://doi.org/10.1016/j.foodcont. 2007.05.006

Li, C.H., Zuo, H.L., Chen, C., Hu, Y.J., Qian, Z.M., Li, W.J., Xia, Z.N., and Yang, F.Q. 2018. SDS-PAGE and 2-DE protein profiles of Ganoderma lucidum from different origins. Pakistan Journal of Pharmaceutical Sciences. 31: 447-454.

Liu, X., Lai, X., Zhang, S., Huang, X., Lan, Q., Li, Y., Li, B., Chen, W., Zhang, Q., and Hong, D. 2012. Proteomic profile of edible bird's nest proteins. Journal of Agricultural and Food Chemistry. 60: 12477-12481. https://doi.org/10.1021/jf303533p

Ma, F., and Liu, D. 2012. Sketch of the edible bird's nest and its important bioactivities. Food Research International. 48: 559-567. https://doi.org/10. 1016/j.foodres.2012.06.001

Mehmeti, I., Kiran, F., and Osmanagaoglu, O. 2011. Comparison of three methods for determination of protein concentration in lactic acid bacteria for proteomics studies. African Journal of Biotechnology. 10: 2178-1285.

Oda, M., Ohta, S., Suga, T., and Aoki, T. 1998. Study on food components: the structure of N-linked Asialo carbohydrate from the edible bird's nest built by Collocalia fuciphaga. Journal of Agricultural and Food Chemistry. 46: 3047-3053. https://doi.org/10.1021/jf980094k

O'Neill, M.A., Denos, M., and Reed, D. 2018. Using SDS-PAGE gel fingerprinting to identify soft-bodied wood-boring insect larvae to species. Pest Management Science. 74: 705-714. https://doi.org/10.1002/ps.4766

Ou, K., Seow, T.K., Liang, R.C., Lee, B.W., Goh, D.L., Chua, K.Y., and Chung, M.C. 2001. Identification of a serine protease inhibitor homologue in bird's nest by an integrated proteomics approach. Electrophoresis. 22: 3589-3595. https://doi.org/10.1002/1522-2683(200109)22:16<3589:: AID-ELPS3589>3.0CO;2-J

Popoola, J., Egwari, L., and Bilewu, Y. 2019. Proximate analysis and SDS-PAGE protein profiling of cassava leaves: utilization as leafy vegetable in Nigeria. MOJ Ecology \& Environmental Sciences. 4: 1-5. 
Quek, M.C., Chin, N.L., Tan, S.W., Yusof, Y.A., and Law, C.L. 2018a. Molecular identification of species and production origins of edible bird's nest using FINS and SYBR green I based real-time PCR. Food Control. 84: 118-127. https://doi.org/10.1016/j.foodcont.2017.07.027

Quek, M.C., Chin, N.L., Yusof, Y.A., Law, C.L., and Tan, S.W. 2018b. Pattern recognition analysis on nutritional profile and chemical composition of edible bird's nest for its origin and authentication. International Journal of Food Properties. 21: 1680-1696. https://doi.org/10.1080/10942912.2018. 1503303

Sahin, Y.M., Su, S., Ozbek, B., Yücel, S., Pinar, O., and Kazan, D. 2018. Production and characterization of electrospun fish sarcoplasmic protein based nanofibers. Journal of Food Engineering. 222: 54-62. https://doi.org/ 10.1016/j.foodeng.2017.11.013

Salim, N.A.A., Othman, Z., Harun, N.A., Moosa, S., Omar, S.A., Azman, M.A., Elias, M.S., Rahman, S.A., Choah, L.C., and Sharif, Z. 2018. A preliminarily study of elemental characterization for geochemical markers of house and cave edible bird's nest using naa technique. Jurnal Sains Nuklear Malaysia. 30: 30-35.

Shim, E.K., Chandra, G.F., Pedireddy, S., and Lee, S.-Y.2016. Characterization of swiftlet edible bird nest, a mucin glycoprotein, and its adulterants by Raman microspectroscopy. Journal of Food Science and Technology. 53: 3602-3608. https://doi.org/10.1007/s13197-016-2344-3

The Star. 2016. Malaysia expected to export 130 tonnes of edible bird's nest. Retrieved on July 17, 2018 from The Star Website https://www.thestar. com.my/business/businessnews/2016/09/05/malaysia-expected-to-export130-tonnes-of-edible-birds-nest/

Tukiran, N.A., Ismail, A., Mustafa, S., and Hamid, M. 2016. Determination of porcine gelatin in edible bird's nest by competitive indirect ELISA based on anti-peptide polyclonal antibody. Food Control. 59: 561-566. https://doi.org/10.1016/j.foodcont.2015.06.039

Tung, C.-H., Pan, J.-Q., Clang, H.-M., and Chou, S.-S. 2008. Authentic determination of bird's nests by saccharides profile. Journal of Food \& Drug Analysis. 16(4): 86-91.

Wong, C.F., Chan, G.K.L., Zhang, M.L., Yao, P., Lin, H.Q., Dong, T.T.X., Li, G., Lai, X.P., and Tsim, K.W.K. 2017. Characterization of edible bird's nest by peptide fingerprinting with principal component analysis. Food Quality and Safety. 1(1): 83-92 https://doi.org/10.1093/fqsafe/fyx002 